DOI: 10.14807/ijmp.v11i8.1218

\title{
INVESTMENT PROVIDING SUSTAINABLE DEVELOPMENT OF RURAL AREAS IN UKRAINE
}

\author{
Svitlana Savitska \\ State Agrarian and Engineering University in Podilya, Ukraine \\ E-mail: svetasavitska@ukr.net
}

Svitlana Zaika Kharkiv Petro Vasylenko National Technical University of Agriculture, Ukraine, Ukraine E-mail: zaika.svitlana1975@gmail.com

Lyudmyla Svystun Poltava National Technical Yuri Kondratyuk University, Ukraine E-mail: mila.poltava@rambler.ru

Liubov Koval Vinnytsia National Agrarian University, Ukraine E-mail: koval.star@meta.ua

Yuliia Haibura IJIM\&P State Agrarian and Engineering University in Podilya KamianetsPodilskyi, Ukraine E-mail: hay.buray@gmail.com

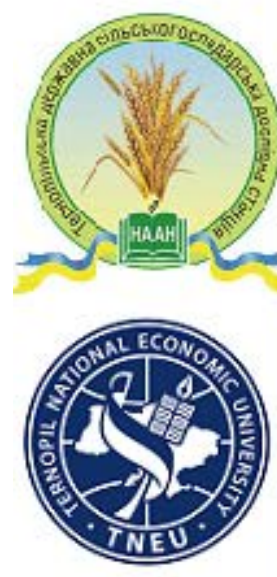

Submission: $12 / 23 / 2019$ Accept: 1/7/2020

\section{ABSTRACT}

The economic growth of agricultural production is one of the main problems of modern economic development of Ukraine, in which investment processes play an important role. Therefore, the research is to reveal the importance of investment for the development of agriculture and rural areas of Ukraine and to develop recommendations to enhance investments in the Ukrainian rural areas. The data base of the State Statistics Service of Ukraine on economic development of Ukraine, investment activity of agriculture in Ukraine and attraction of foreign direct investments into the economy of Ukraine for 2014-2018 served as the information base for empirical and statistical research. It is found according to the results of the study that the level of provision of agriculture with investment resources is not sufficient. 
DOI: 10.14807/ijmp.v11i8.1218

The reason is a number of negative factors: imperfect legislative framework, corruption, economic instability of the country, military conflict in the east of the country, insufficient financing of agriculture, low level of credit to the sector, etc. Using a systematic and integrated method, a model for the formation of investment support for sustainable rural development has been developed. We believe that in order to activate the sustainable development of rural territories, the use of the model will help to streamline and allocate financial and investment resources and improve rural investment activities

Conceptual approaches to the possible introduction of the agricultural land market in Ukraine are substantiated.

Keywords: investment; investment support; rural areas; investment climate; land market.

\section{INTRODUCTION}

The agrarian sector of Ukraine is, in its essence, a rather attractive branch of the economy, given its natural resource base, favorable climatic conditions, economic activity and transport and transit opportunities. (GRAIN SECTOR OF UKRAINE... 2007). However, many agricultural enterprises are lacking their own funds to invest in fixed assets (NABIEVA; DAVLETSHINA, 2015). Today, Ukraine has a single integrated strategy for the development of agriculture and rural areas for 2015-2020.

It is aimed at comprehensively pursuing a number of reforms, which have long been awaited by agricultural producers, agricultural businesses and the rural population (UNIQUE COMPLEX... 2015). State support for agricultural enterprises is realized through the provision of subsidies for the period from January 1, 2017 to January 1, 2022, to support them at least in connection with the abolition of the special VAT regime. Funds for this were provided in the State Budget for 2017-2019.

Thus, expenditures for agribusiness development programs in the budget of 2017 amounted to UAH 3.7 billion, of which UAH 2.2 billion was allocated from the general fund and UAH 1.5 billion from the special fund. Support for the development of agricultural enterprises is envisaged in the following areas, such as cheaper loans (UAH 300 million); support of events in the agro-industrial complex (55 million UAH ..); support for and supervision of young gardens, vineyards and berries, (UAH 75 million); providing loans to farms (UAH 25 million); support for animal husbandry (UAH 210 million); financial support to agricultural producers (UAH 1.5 million) (STATE SUPPORT ... 2018). 
DOI: 10.14807/ijmp.v11i8.1218

For example, the EU Common Agricultural Policy budget for 2014-2020 provides for direct payments to agricultural producers and market measures of EUR 308.7 billion, which is EUR 238 / ha. In addition, EUR 99.6 billion has been earmarked for rural development, which is 1: 0.3225 in proportion to direct investment in production. If we impose these indicators on the parameters of Ukraine, in 2017 only 215 should be directed to the development of agricultural production and UAH 69 billion to rural development, which is 4.3 and 5 times more than the actual volume of capital investments, respectively.

However, there are as yet no EU support mechanisms and subsidies in Ukraine, and the actual investment in agriculture (\$ 75 per 1 ha) in 2017 is only matched by developing countries (up to \$ 150 per capita). 1 ha) (KISIL, 2018).

Therefore, substantiation of the additional measures and resources to attract investment and ensure the sustainable development of rural areas of Ukraine, their effective use and the development of an appropriate implementation mechanism is an urgent task.

\section{LITERATURE REVIEW}

Investment, as an economic category, is an extremely meaningful and multifaceted phenomenon that has been extensively studied by scholars of the world for centuries. First views on the essence of investments, stimulation of the investment process of reflection in the writings of mercantilists in the XV-XVII centuries, in particular T. Men and J. Colbert. They adhered to the principles that the source of wealth and investment is trade capital, which is formed through successful foreign trade operations (MAKHOVYKOVA, 2005).

Keynes argued that investments are an increase in the value of capital goods on the one hand and, on the other, the value of production consumption of newly created tangible goods and services. And investment is the incremental increase in the value of capital property as a result of production activities of a certain period, that is, the use of that part of profit that has not been used for consumption (KEYNES, 1999)

Investments as a subject of special study in the economic science have become a problematic issue at the turn of the XX-XXI centuries. According to W. Sharp, "to invest" in the broadest sense means "to part with money today to have more money in the future" (SHARP, 2003). L. Hitman defines investment as a way of capital allocation, which should ensure that its value is maintained or increased and (or) yield a positive amount of income (GITMAN, 1999). 
DOI: 10.14807/ijmp.v11i8.1218

The same content of investments is reflected in the writings of Ukrainian economists, in particular I. Blank (BLANK, 1995), V. Fedorenko (FEDORENKO, 1999), where it is noted that investment is an investment (expenditure) of money and capital in order to further increase it, income generation, or both. Similar is the definition of K. McConnell and S. Brue (MCCONNELL; BRUE, 2003) investments are the costs of production and accumulation of means of production, increase in inventories and so on. T. Mayorova (MAYOROVA, 2013) analyzed the nature of the investment process and explored ways to improve the economic mechanism.

These studies confirm the need for a possible social and economic impact of a deeper understanding of investment, particularly in rural areas, in the absence of detailed research in this area (DYBA; GERNEGO, 2018). According to the Law of Ukraine "On Investment Activity”, investments are property and intellectual values that are invested in objects of entrepreneurial and other types of activity, as a result of which profit (income) or social effect is achieved (the Low of Ukraine “ON INVESTMENT ACTIVITY”, 2019) .

Activation of investment activity is a basic condition for stable development of region development, which is able to attract financial and material resources of both domestic and foreign investors, as well as use them rationally in the most priority sectors of the economy (TOMASCHUK, 2018).

Particularly urgent is the problem of development of investment support for rural areas of Ukraine (KISIL, 2018; TOMASCHUK, 2018). Investment security is the process of accumulating the required amount of investment resources through the implementation of an appropriate investment policy. Investment policy is the implementation of investment activities aimed at the complex transformation of production and economic and management activities (FEIER, 2016).

Investment support in the sustainable development of rural territories depends to a large extent on their investment attractiveness and development of investment potential (RUSNAK, 2015; TYMOSHENKO, 2018; KISIL, 2018; TOMASCHUK, 2018). Creating a favorable investment climate and investment potential is a prerequisite for increased investment and economic growth of the country (NABIEVA; DAVLETSHINA, 2015).

Therefore, investment policy should be based on a comprehensive approach that combines mechanisms of investment support, development of investment potential of the 
DOI: 10.14807/ijmp.v11i8.1218

country, its regions and industries (FEIER, 2016; MOROZ, 2013; KISIL, 2018; RUSNAK, 2015).

The scientific problems of the article are in the coverage of issues of investment support for agriculture and rural areas, including trends in their development. The purpose of the article is to develop measures to intensify investment processes in Ukrainian rural areas and to prove the possibility of improving the situation of rural development through the model of financial and investment support. The object of the research is the investment activity of agriculture and rural territories of Ukraine. The subject is the investment in agriculture.

\section{DATA AND METHODOLOGY}

The methodology of the study is based on the analysis of foreign and Ukrainian scientific literature used to describe the nature of investments and investment support. The statistics of the last five years are used to analyze the trends of investment in agriculture and rural development in Ukraine.

\section{RESULTS AND DISCUSSIONS}

The development of rural areas is inextricably linked to agricultural production. $18 \%$ of economically active population is employed in agriculture of Ukraine (AGRICULTURE OF UKRAINE, 2019). The share of persons employed in agricultural enterprises increased by $0.9 \%$, which indicates its development as one of the main areas that provide job creation, is shown in the period 2014-2018 in the country (Fig. 1). The share of gross value added created in agriculture of the country was $11.9 \%$ in 2018 , compared to $11.7 \%$ in $2014,14.2 \%$ in 2015 , 2016 - 13.8\%, 2017 - 12.1\% (AGRICULTURE OF UKRAINE, 2019).

If we analyze the volume of gross value added in the agriculture of Ukraine (Fig. 2), we see a dynamic growth from UAH 161145 million in 2014 to UAH 360757 million, in 2018, up 2.2 times. Partually, this situation can be explained by the increase in investment resources for rural development and agricultural production. If 18796 million UAH was spent in 2014, then in 2018 it was UAH 66104 million, which is 3.5 times more. The share of capital investments in 2014 was 8.6\%, in 2015 - 11\%, in 2016 - 14.1\%, in 2017 - 14.3\%, in $2018-11.4 \%$ (CAPITAL INVESTMENTS 2019).

Despite the fact that the largest amount of investments was made in 2018 over the analyzed period, its share in the overall structure decreased slightly compared to previous years. Thus, the volume of capital investments made in the agricultural sector of Ukraine in 2018 increased by $14.0 \%$ compared to 2017 in the prices of the respective years. 
ISSN: 2236-269X

DOI: 10.14807/ijmp.v11i8.1218

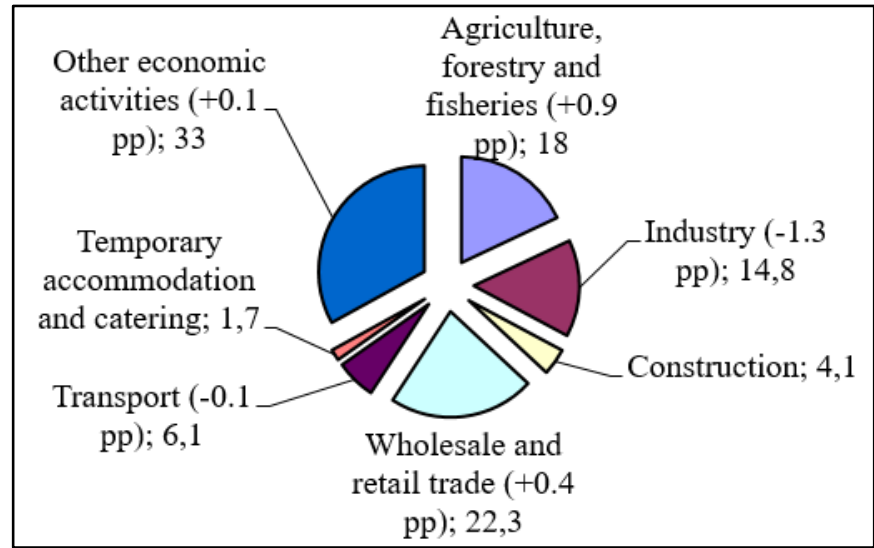

Figure 1: Number of employed population by type of economic activity,\%

* Source: it is based on data from the State Statistics Service of Ukraine (AGRICULTURE OF UKRAINE, 2019)

However, given inflation, their real growth was only 8.5\%. This is the lowest rate of growth of capital investments in the last three years: in 2016 it was $49.5 \%$ and in $2017-30.7 \%$ (KISIL, 2019).

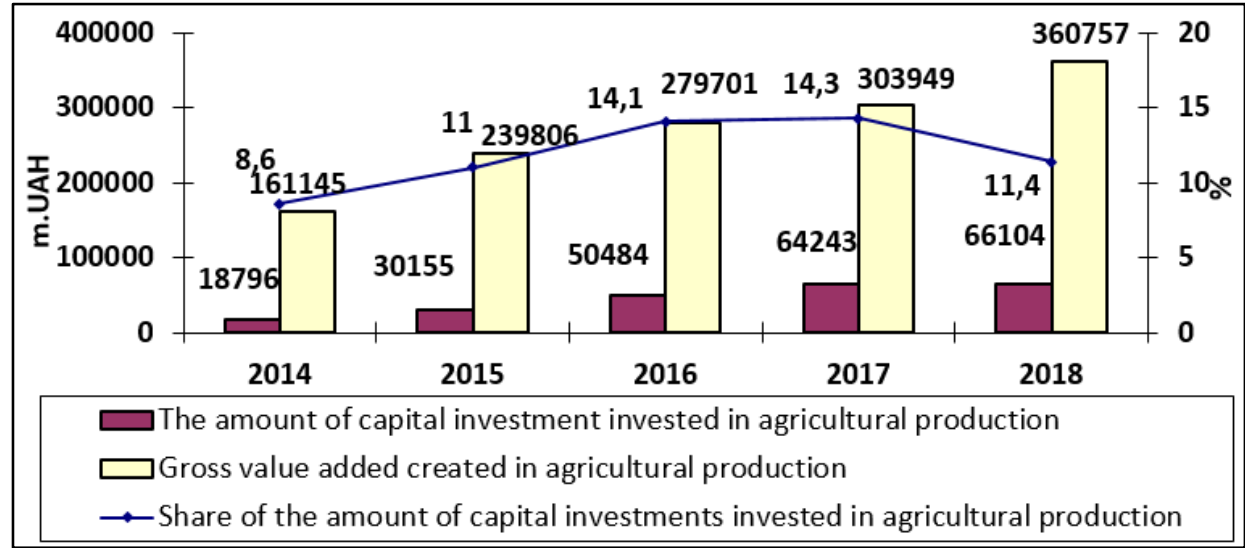

Figure 2: Gross value added in agriculture and the amount of capital investment in 2014-2018 * Source: it is based on data from the State Statistics Service of Ukraine (AGRICULTURE OF UKRAINE, 2019; CAPITAL INVESTMENTS, 2019)

Capital investments by the types of assets, namely land, in 2018 amounted to UAH 1360.5 million that is UAH 79.5 million more than in 2017 and by UAH 75.6 million less than in 2016 (Fig. 3). On the other hand, the share of the amount of capital investments utilized in the land decreased by 13\% (CAPITAL INVESTMENTS BY THE TYPES OF ASSETS, 2019).

This nature of the dynamics of capital investment on the development of the agricultural sector of Ukraine is due to a set of factors, in which the effect of negative increases. In conditions of military action in the eastern part of the country, budget expenditures to support agricultural producers are reduced. Due to instability, agro-companies favor investment in the growth of current assets, which, although they bring quick benefits but narrow down the prospects for strategic development. Due to the increased risk level, large agro-companies are 
DOI: 10.14807/ijmp.v11i8.1218

pushing investment resources into more secure areas for their capital. Investment in small agribusiness, which is one of the most important drivers of development, has slowed down.

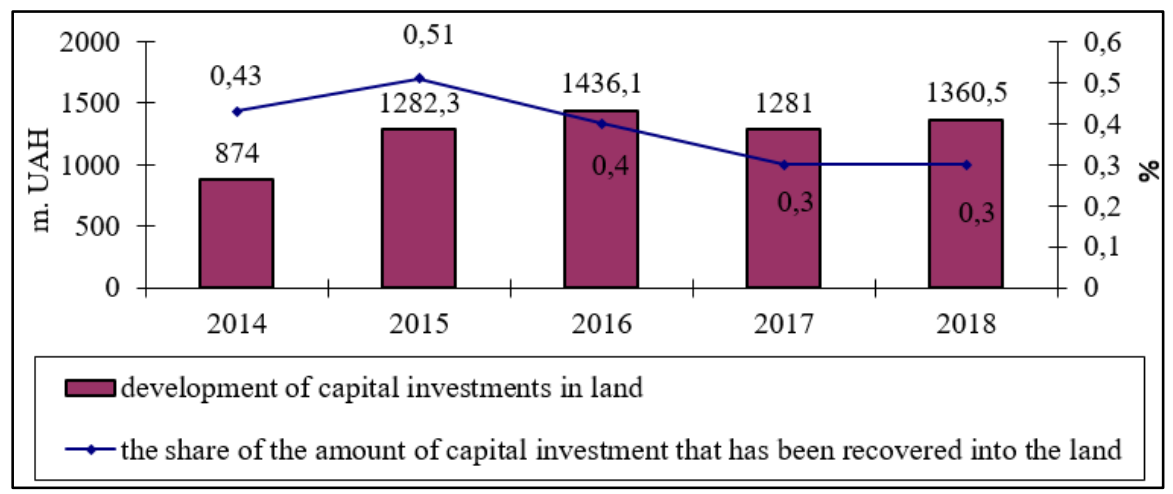

Figure 3: Dynamics of capital investments by the types of assets (land) 2014-2018 mln.

* Source: it is created by the authors based on (CAPITAL INVESTMENTS BY THE TYPES OF ASSETS, 2019)

Despite the increasing negative factors, the production of agricultural products in comparison with the food industry still remains investment attractive. In 2018, capital expenditures on food, beverage and tobacco production amounted to UAH 2.81, corresponding to agriculture, hunting and related services. For comparison, this indicator in 2009 was 1.00 UAH / UAH; 2012 - 1,40 UAH / UAH; 2015 - 2,16 UAH / UAH; 2017 - 2.35 UAH of capital investment in agriculture, hunting and related services for $1 \mathrm{UAH}$ of capital investment in food production (KISIL, 2019).

Let us consider in more detail the distribution of capital investments by sources of investment (Fig. 4) The main source of financing of capital investments is the own funds of the enterprises and organizations which provided 86.8\% of capital investments in 2018 (UAH 57378.07 million) (CAPITAL INVESTMENTS BY SOURCES..., 2019). It can be concluded that the main burden on investments is borne by the agricultural enterprises themselves, in fact financing the production from their own profit.

Funds of foreign investors amounted to UAH 4.07 million, which is very low. Attracting foreign capital in the agricultural sector provides for the formation of fundamental changes in the direction of their innovative development. 
ISSN: $2236-269 X$

DOI: 10.14807/ijmp.v11i8.1218

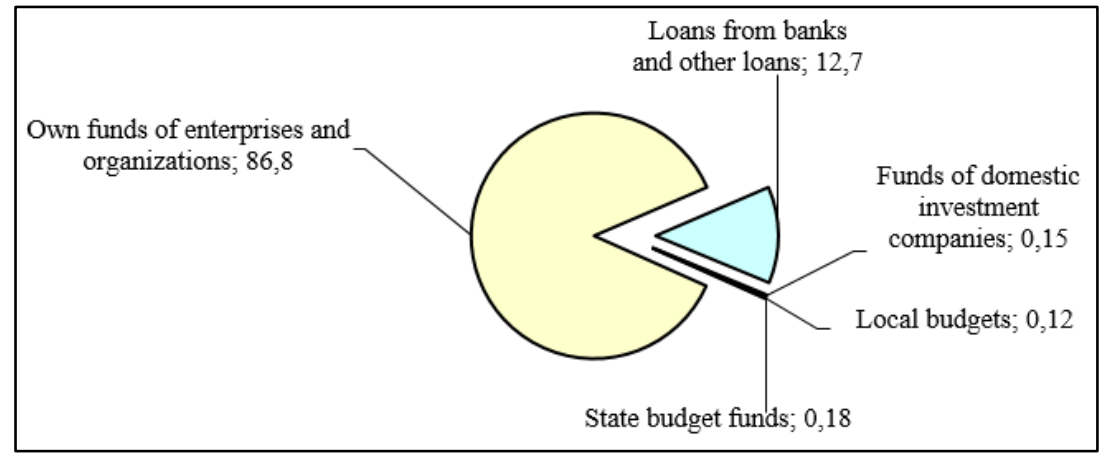

Figure 4: Distribution of capital investments into agricultural enterprises by sources of financing in 2018,\%

* Source: it is created by the author based on (CAPITAL INVESTMENTS SOURCES..., 2019)

This leads to the fact that agrarian enterprises often have new investors, partners, updated technical and material base involved in the production process, introduce new technologies, ensure the skills of workers, search for new markets and raw materials, offer new jobs places, the level of wages is rising (VOLCHANSKA, 2017).

The share of state and local budget funds is quite small and amounts respectively to 0.18\% (UAH 116.6 million) and 0.12\% (UAH 80.9 million). The share of bank loans in total investments is $12.7 \%$ (UAH 84008 million) (CAPITAL INVESTMENTS BY SOURCES... 2019). This means that the investment activity of small agribusiness, which is one of the most important factors of development, is slowed down.

A dynamic inflow of foreign capital cannot be expected with such an internal investment situation. Thus, the share of foreign direct investment in agriculture and rural development in total investment increased from 1.4\% in 2014 to 1.9\% in 2017 against the backdrop of the overall decline in investment (Table 1). Direct investment (equity) in Ukrainian agriculture declined in terms of value. The volume of foreign direct investment in the sector reached \$ 776.9 million As of January 1, 2014 and it dropped to \$ 578.6 million as of January 1, 2018. (DIRECT INVESTMENTS... 2019).

Table 1: Dynamics of volumes and growth of foreign direct investments in Ukraine

\begin{tabular}{|l|c|c|c|c|c|}
\hline \multicolumn{1}{|c|}{ Indicators } & $\mathbf{2 0 1 4}$ & $\mathbf{2 0 1 5}$ & $\mathbf{2 0 1 6}$ & $\mathbf{2 0 1 7}$ & $\mathbf{2 0 1 8}$ \\
\hline $\begin{array}{l}\text { Total foreign direct investment in the } \\
\text { economy of Ukraine, million US dollars }\end{array}$ & 53704 & 38356,8 & 32122,5 & 31230,3 & 31606,4 \\
\hline $\begin{array}{l}\text { Foreign direct investment in agriculture, } \\
\text { forestry and fisheries, million US \$ }\end{array}$ & 776,9 & 617,0 & 502,2 & 586,2 & 578,6 \\
\hline $\begin{array}{l}\text { Share of foreign direct investment in } \\
\text { agriculture, forestry and fisheries in total } \\
\text { investment, million US \$ }\end{array}$ & 1,4 & 1,6 & 1,6 & 1,9 & 1,8 \\
\hline $\begin{array}{l}\text { The increase in foreign direct investment in } \\
\text { agriculture, forestry and fisheries,\% }\end{array}$ & 8,23 & $-20,58$ & $-18,6$ & $-0,42$ & $-1,29$ \\
\hline
\end{tabular}

* Source: it is calculated based on data (DIRECT INVESTMENT ... 2019) 
DOI: 10.14807/ijmp.v11i8.1218

Looking at the economic indicators, we can see that there has been a decline in FDI in Ukraine in the last 2 years and their volume per capita remains negligible when compared to other European countries (just over \$ 1.000 per year) (KUZIUTKIN, 2019).

The agricultural sector continues to hold the position of the most attractive area for investment (KISIL, 2018; KUZIUTKIN, 2019). Among recently surveyed EVA foreign investors, almost $90 \%$ today consider Ukraine as an attractive country for investment (KUZIUTKIN, 2019). It should be noted that in the rating of the agency Moody's Investors Service Ukraine has improved its credit rating in the international economic list. It changed from Caa3 to Caa2, which means changing the forecast from "stable" to "positive".

Thus, the improvement of indicators was influenced by the implementation of structural reforms in Ukraine, which helped the country to cope with the debt load and improve its position in foreign markets. In the Global Competitiveness Index (GCI) 2017/2018, Ukraine improved its position by 4 points and ranked 81st among 137 countries surveyed (in GIC 2016/2017 - 85th out of 138 countries) (KOLEVATOVA, 2018).

Formation of favourable investment climate of Ukraine is a prerequisite for gradual recovery of economic growth of the country. Therefore, state investment policy should be based on a comprehensive approach that combines mechanisms for developing the investment potential of a country, its regions and industries. In modern conditions, sustainable rural development is a priority of the state agrarian policy aimed at improving the quality of life of the population, increasing the efficiency of agricultural production, developing a multifunctional rural economy, preserving the environment, etc. (TOMASCHUK, 2018).

Sustainable social and economic development of rural areas depends on the development and implementation of an effective model of its financial and investment support, which is a set of ways of organizing financial relations, which is used in specific conditions of functioning and development of rural areas.

The Rural Development Investment Facility acts as a regulator that defines the direction and proportions of the distribution of financial and investment resources and lays the foundation for the possibility of developing a Ukrainian village with a developed market economy (BADYK, 2013).

The successful functioning of the mechanism of investment support for sustainable development of rural territories will be facilitated by the developed model (Fig. 5), the 
DOI: 10.14807/ijmp.v11i8.1218

implementation of which largely depends on the investment attractiveness of agro-industrial complex.

Formation of a favorable investment climate, attraction of foreign investors and increase of national investment resources in rural development hinders a number of negative factors, the most acute of which are: unstable, unpredictable and opaque state policies characterized by the absence of uniform rules of the game for all producers and sectors, excessive government interference into the work of agrarian markets, lobbying of individual interests for monopoly rent; lack of financing for agriculture, low level of lending to the sector compared to similar countries; lack of efficient and accessible infrastructure of agricultural markets and marketing system; ineffective government policies to support exporters; the vulnerability of the current business model of large agricultural holdings: dependence on changes in the external environment, the need for debt servicing (external borrowing), and lack of ownership of land (YERMOLAIEV et al., 2015; RUSNAK, 2015).

Currently, investments in the agricultural sector are more focused on the acquisition of assets, corporate rights and leased land rights. However, it is obvious that the practical impossibility of acquiring agricultural land into private ownership is alienating to most foreign investors, as it is a great risk given the political situation in the country (KUZIUTKIN, 2019). Land relations and the land market is the first thing that interests potential investors when coming to Ukraine.

The implementation of land reform in Ukraine actually began in 1992 with the divestment of agricultural land for the purpose and the imposition of a moratorium on its purchase and sale. The need for the removal of the moratorium has been actively debated for at least the last ten years, with the moratorium being extended every time.

The peasants will have the right to dispose of the land they own, at their discretion - to bail, to sell. In particular, they will have the opportunity to sell their unit, it will also increase the cost of renting the land, that is, will provide more income for its owners. The villagers will be able to obtain bank financing secured by land for the development of their own businesses and attracting investments. They will also be able to combine land assets and create joint ventures for more efficient production.

It is expected to increase the volume of investments in the agricultural sector and more efficient allocation of land resources, launch a mechanism for the emergence of land owners who are ready to cultivate it and invest in increasing productivity and efficiency of such 
INDEPENDENT JOURNAL OF MANAGEMENT \& PRODUCTION (IJM\&P)

http://www.ijmp.jor.br

v. 11, n. 8, Special Edition ISE, S\&P - May 2020

ISSN: 2236-269X

DOI: 10.14807/ijmp.v11i8.1218

cultivation. Agroholdings will also be more interested in efficient and prudent use of their own resources. As a consequence, we can expect an increase in long-term investment in high-tech land cultivation.

The development of a land market will help transport and social infrastructure in rural and rural areas. Investors will be interested in creating and facilitating the development of highways and railroads, electrification and gasification, Internet connection (YERMOLAIEV et al., 2015).

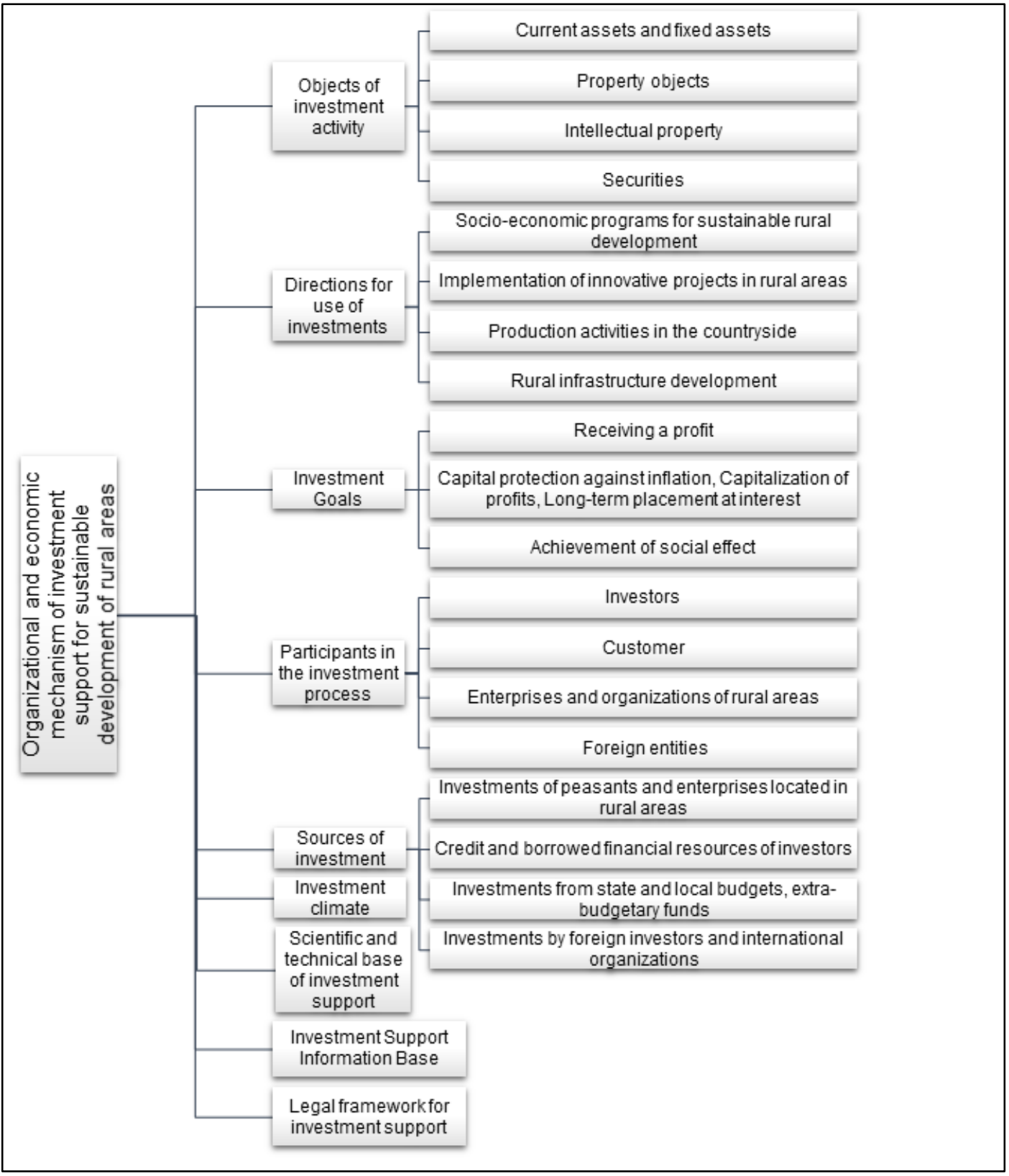

Figure 5: Model of formation of investment support for sustainable development of rural territories

Source: it is improved by authors based on (MOROZ, 2013; RUSNAK, 2016) 
DOI: 10.14807/ijmp.v11i8.1218

The main arguments "against" the rapid abolition of the moratorium on land sales: institutional unpreparedness; corruption, inefficient judicial system and low level of protection of property rights in Ukraine at the moment; unfavorable economic situation for opening the land market; the threat of mass sales and concentration of land in one hand; the threat of speculation, forced sale and raiding.

Using land as collateral for loans, Ukrainian farmers are potentially able to raise at least \$ 20 billion or more than $\$ 100$ billion annually to update fixed assets and ensure their operations (GRAIN SECTOR OF UKRAINE, 2007). Thus, agricultural land, in addition to its own means of production, can and should become a source of investment, as is the case in other developed countries. Without this, there is no hope for any significant level of investment in Ukrainian agriculture.

Other equally important steps to improve the investment climate in Ukraine are the creation of a state-owned specialized land mortgage bank through which the state would be able to regulate the credit market and mortgage operations in the agro-industry, the formation of cooperatives in rural areas to improve the process of buying and selling agricultural products, the creation of wholesale agricultural markets, especially near large cities, where farmers would be able to sell their products directly and market prices.

The interaction of science, education and the practical implementation of the latest developments and communicating them to producers through a network of advisory services would also contribute to the introduction of know-how and the intensification of production, which in turn would make agriculture and rural areas more competitive and attractive to investors. (GRAIN SECTOR OF UKRAINE ..., 2007).

\section{CONCLUSIONS AND RECOMMENDATIONS}

The research results show that the system of investment support for rural development is formed under the influence of social and economic, financial and economic, economic and legal factors based on the interconnection of such components as: legal framework, human resources, organizational and economic, scientific, innovative, information, financial, technical and marketing support, which will enhance its sustainable development.

Today, agriculture is one of the leading sectors of the Ukrainian economy, which has significant natural competitive advantages. However, the level of investment in the fixed capital of the agricultural sector is still limited. It is necessary to support changes in legislation with proper implementation in order to improve the investment climate in Ukraine, as well as 
DOI: 10.14807/ijmp.v11i8.1218

to show potential investors successful examples, profitability and protection of their contributions.

The model of the mechanism of investment support for sustainable development of rural territories that is proposed by the authors will allow to streamline and improve investment activity, which, in turn, will become a reliable basis for creating modern industries, increasing the number of efficient jobs, increasing the welfare and solvency of the local population.

Although there are a number of arguments both "for" and "against" the abolition of the moratorium, we believe that the gradual opening of the land market after the abolition of the moratorium will increase investment in the agrarian sector and help to create a state specialized land mortgage bank.

\section{REFERENCES}

BADYK, A. (2013) Teoretychna struktura mekhanizmu finansovoho zabezpechennya rozvytku silskykh terytoriy [Theoretical structure of the mechanism of financial support for rural development]. Innovative economy, n. 3, p. 156-162. (in Ukranian)

BLANK, Y. (1995) Investytsiinyi menedzhment [Investment management]. Kyiv: MP "YTEM" (in Russian)

DERZHAVNA PIDTRYMKA AHRARNOHO SEKTORU U 2017 ROTSI (2018) State support for the agricultural sector in 2017. Available at: <: http:// www.auu.org.ua/uk/publications/web/206. Access: 18 October 2019 (in Ukranian)

DYBA, M.; GERNEGO, I. (2018) Private social investments as a solution for rural development. Management Theory and Studies for Rural Business and Infrastructure Development, v. 40 n. 3, p. 320-328.

FEDORENKO, V. (1999) Investytsiinyi menedzhment [Investment management]. Textbook allowance. Kyiv. MAUP (in Ukranian)

FEYER, O. (2016) Investytsiine zabezpechennia diialnosti vitchyznianykh pidpryiemstv [The investment support of national enterprises]. Scientific Bulletin of Mukachevo State University, v. 2, p. 112-117. Available at:

http://dspace.msu.edu.ua:8080/jspui/bitstream/123456789/2609/1/2-6-2-2016-19.pdf . Access: 6 October 2019. (in Ukranian)

HUTOROVA, O. (2016) Problemy ta perspektyvy rozvytku silskykh terytorii v Ukraini. [Problems and prospects of rural areas' development in Ukraine] Problems of an innovative economy, n. 4, p. 68-73. Available at: http://journals.uran.ua/index.php/25240455/article/view/90410/86170. Access: 9 October 2019 (in Ukranian)

HITMAN, L.; DZHONK, M. (1997) Osnovy investurovannia [Investment fundamentals]. Moskow: Dillo (in Ukranian)

KAPITALNI INVESTYTSII ZA VYDAMY EKONOMICHNOI DIIALNOSTI ZA 20102018 ROKY (2019) Capital investments by type of economic activity for 2010-2018. Available at: 
DOI: 10.14807/ijmp.v11i8.1218

https://ukrstat.org/uk/operativ/operativ2013/ibd/ibd_rik/ibd_u/ki_rik_u_e_bez.htm. Access: 28 October 2019 (in Ukranian)

\section{KAPITALNI INVESTYTSII ZA DZHERELAMY FINANSUVANNIA ZA VYDAMY EKONOMICHNOI DIIALNOSTI ZA 2018 (2019) Capital investments by sources of} financing by type of economic activity for 2018. Available at:

http://www.ukrstat.gov.ua/operativ/operativ2019/ibd/kindj_ek/arch_kindj_ek.htm. Access: 28 October 2019 (in Ukranian)

KAPITALNI INVESTYTSII ZA VYDAMY AKTYVIV (2019) Capital investment by asset type. Avaible at: <

http://www.ukrstat.gov.ua/operativ/operativ2018/ibd/kinv/kinv_2018_u.htm. Access: 29

October 2019 (in Ukranian)

KEYNS, D. (1999) Obshchaia teoryia zaniatosty, protsenta y deneh [The General Theory of Employment, Interest, and Money]. Avaible at:

https://cas2.umkc.edu/economics/people/facultypages/kregel/courses/econ645/winter2011/ge neraltheory.pdf. Access: 5 November 2019

KISIL, M. (2018) Investytsiine zabezpechennia rozvytku silskoho hospodarstva Ukrainy v stratehichnii perspektyvi [Investment support for the development of Ukraine's agriculture in a strategic perspective]. Bulletin of Agricultural Science, v. 1, n. 778, p. 78-82. Avaible at: http://nbuv.gov.ua/UJRN/vaan_2018_1_15. Access: 19 October 2019 (in Ukranian)

KISIL, M. (2018) U 2018 rotsi upovilnylasia dynamika kapitalnykh investytsii v ahrosektor [In 2018, the dynamics of capital investments in the agricultural sector slowed down]. Avaible at: https://agropolit.com/news/11666-u-2018-rotsi-upovilnilasya-dinamikakapitalnih-investitsiy-v-agrosektor. Access: 29 October 2019 (in Ukranian)

KOLEVATOVA, A. (2018) Suchasnyi stan zaluchennia inozemnykh investytsii v ekonomiku Ukrainy [The current state of attracting foreign investment in the economy of Ukraine].

Global and national problems of the economy. v. 22, p. 1080-1084. Avaible at: http://global-national.in.ua/issue-22-2018/30-vipusk-22-kviten-2018-r/4052-kolevatova-a-vsuchasnij-stan-zaluchennya-inozemnikh-investitsij-v-ekonomiku-ukrajini. Access: 26 October 2019 (in Ukranian)

KOZYUTKIN, L. (2019) Kolo interesiv: Top-3 napriamky investytsii v Ukrainu [Range of interests: Top 3 areas of investment in Ukraine] Legal Newspaper. All-Ukrainian weekly professional legal publication. Avaible at: http://yur-gazeta.com/dumka-eksperta/kolointeresiv-top3-napryamki-investiciy-v-ukrayinu.html. Access: 21 SEPTEMBER 2019 (in Ukranian)

MAKHOVYKOVA, H.; BYZOVA, I. (2005) Investytsii [Investments]. SPв: Piter. (in Russian)

MAYOROVA, T. (2013) Investycijnyj proces i finansovo-kredytni vazheli joho aktyvizaciyi v Ukrayini [The investment process and financial and credit levers of its activation in Ukraine]: monograph. Kyiv: KNEU. Avaible at: https://core.ac.uk/download/pdf/32610803.pdf. Access: 2 November 2019 (in Ukranian)

MCCONNELL, C.; BRUE, S. (2007) Economics: principles, problems, and policies. McGRAW-Hill. Irwin.

MOROZ, T. (2013) Investytsiine zabezpechennia staloho rozvytku silskykh terytorii [Investment support for sustainable rural development]. Innovative economy, v. 4, n. 42, p. 132-135. Avaible at: 
http://dspace.mnau.edu.ua/jspui/bitstream/123456789/2782/1/Інноваційна\%20економіка.pd f. Access: 4 October 2019 (in Ukranian)

NABIEVA, L.; DAVLETSHINA, L. (2015) Return On Investments In The Formation Of Fixed Capital Assets In Agriculture Of The Republic Of Tatarstan. Procedia Economics and Finance, v. 24, p. 457-463

PRIAMI INVESTYTSII (AKTSIONERNYI KAPITAL) V EKONOMITSI UKRAINY Z KRAIN SVITU U ROZRIZI VYDIV EKONOMICHNOI DIIALNOSTI U 2018 ROTSI (2019) Direct investment (equity) in the economy of Ukraine from the countries of the world in terms of economic activities in 2018. Avaible at:

http://www.ukrstat.gov.ua/operativ/operativ2018/zd/inv_zd/pi_ak_ks_ved/arh_pi_ak_ks_ved _u.html. Access: 30 October 2019 (in Ukranian)

RUSNAK, A. (2016) Formuvannia investytsiinoi modeli staloho rozvytku silskyi terytorii rehioniv Ukrainy [The formation of the investment model of sustainable development of rural territories of the regions of Ukraine]. Young scientist, v. 1, n. 16, p. 50-53. Avaible at: http://nbuv.gov.ua/UJRN/molv_2015_1\%282\%29_13. Access: 1 October 2019 (in Ukranian)

SHARPE, W.; ALEKSANDER, G.; BEYLY, J. (1998) Investments, Prentice Hall, Upper Saddle River, NJ.

SILSKE HOSPODARSTVO UKRAINY (2019) [AGRICULTURE OF UKRAINE]. Statistical Digest. Kuiv: State Statistics Service of Ukraine. (in Ukranian)

TOMASHCHUK, I. (2018) Investytsiinyi potentsial silskykh terytorii: osnovni aspekty rozvytku [Investment potential of rural areas: basic aspects of development]. Sustainable economic development. International scientific and production journal, v. 1, n. 38, p. 140149. Avaible at: http://www.vsau.vin.ua/repository/getfile.php/16897.pdf. Access: 30 October 2019 (in Ukranian)

TYMOSHENKO, M. (2018) Neobkhidnist ta shliakhy zrostanniaia investytsiinoi pryvablyvosti silskykh terytorii na zasadakh inkliuzyvnosti [Necessity and ways of growth of investment appeal for rural areas on the basis of inclusion]. Podilian Bulletin: Agriculture, Technology, Economics, v. 29, p. 186-195. Avaible at: http://pb.pdatu.edu.ua/article/view/162416/161391. Access: 30 October (in Ukranian)

VOLCHANSKA, L. (2017) Formuvannia investytsiinoi pryvablyvosti ahrarnykh pidpryiemstv [Formation of investment attractiveness of agricultural enterprises]. Dnipro: DDAY. Avaible at: https://www.dsau.dp.ua/ua/page/photo/aref_volchanska.PDF. Access: 30 October 2019 (in Ukranian)

YEDYNA KOMPLEKSNA STRATEHIIA TA PLAN DII ROZVYTKU SILSKOHO HOSPODARSTVA TA SILSKYKH TERYTORII V UKRAINI NA 2015 - 2020 ROKY (2015) Unified comprehensive strategy and action plan for the development of agriculture and rural territories in ukraine for $\mathbf{2 0 1 5}$ - 2020. Avaible at:

http://search.ligazakon.ua/__doc2.nsf/link1/NT1978.html. Access: 12 October 2019 (in Ukranian)

YERMOLAYEV, A.; KLYMENKO, I.; YEMETS, V.; TARAN, S. (2015) Ahrarnyi sektor Ukrainy: tendentsii, subiekty, perspektyvy reformuvannia [The agricultural sector of Ukraine: trends, subjects, prospects for reform]. New Ukraine. Institute for Strategic Studies Available at: http://newukraineinstitute.org/media/news/549/file/Agro\%202015.pdf. Access: 16 October 2019 (in Ukranian) 
ISSN: 2236-269X

DOI: 10.14807/ijmp.v11i8.1218

ZAKON UKRAINY «PRO INVESTYTSIINU DIIALNIST» (1991) The Law Of Ukraine "On Investment Activities" No. 1560-Xii Of September 18. 1991. Avaible at: < https://zakon.rada.gov.ua/laws/show/1560-12> Access: 2 November 2019 (in Ukranian) ZERNOVYI SEKTOR UKRAINY: TENDENTSII TA PERSPEKTYVY (2007) [GRAIN SECTOR OF UKRAINE: TRENDS AND PROSPECTS]. Canadian-Ukrainian Grain Project II. Kuiv (in Ukranian) 